\title{
Analysis of Critical Land Based on the Erosion and Soil Organic Carbon in the Watershed of Girindulu East Java Province, Indonesia
}

\author{
Djafar Mey ${ }^{1, *}$, Ahmad Iskandar ${ }^{2}$, Junun Sartohadi $^{3}$, Djati Mardiatno ${ }^{3}$, Muh Aris \\ Marfai $^{3}$, La Ode Safuan ${ }^{4}$, La Ode Amaluddin ${ }^{1}$, Muhamad Tufaila ${ }^{5}$, Baharudin ${ }^{6}$ \\ ${ }^{I}$ Department of Geography, Universitas Halu Oleo, Kendari, Indonesia \\ ${ }^{2}$ Department of Geography Education Universitas Sembilanbelas November Kolaka Kolaka, Indonesia \\ ${ }^{3}$ Faculty of Geography Universitas Gadjah Mada, Yogyakarta, Indonesia \\ ${ }^{4}$ Department of Agrotecnology Universitas Halu Oleo Kendari, Indonesia \\ ${ }^{5}$ Department of Soil Science, Universitas Halu Oleo, Kendari, Indonesia \\ ${ }^{6}$ Balai Pengkajian Teknologi Pertanian, Kendari, Indonesia \\ *Corresponding author. Email: djafarmey1970@yahoo.com
}

\begin{abstract}
This study aims to analyze the relationship between erosion, soil organic carbon content with land critical. This research uses a geomorphology approach with the landform as the unit of analysis. Land critical is determined by the grade level of erosion hazard and soil organic carbon content class, taking into account the value of the fraction of silt and clay. The result showed that erosion process can cause the land to become critical and uncritically. This is proven by the results of the research, showed that $43.49 \%$ is categorized as critical land, $25.99 \%$ very critical, $14.70 \%$ medium critical, $8.41 \%$ somewhat critical, and uncritical land $7.41 \%$ or widest 5461,89 ha from the total area of Girindulu Watershed. Therefore, it can be concluded that critical land is extremely depended on the process of erosion and soil organic carbon content.
\end{abstract}

Keywords: erosion, soil organic carbon, critical land, Girindulu Watershed

\section{INTRODUCTION}

Critical land is defined as an area which has been decreased its function up to a certain degree because of land damage [1]. The main factor causing this matter is erosion. Erosion can come up because of the interaction between some factors, such as climate, topography, plants, and human. Rainfall is the most important factor that has a role in the erosion. The heavy rainfall has the most erosive effect compared to low rainfall [2]. The kinetic energy of rainfall is able to destruct, break down, release, and sweep out material on the soil surface [3]. Destructing power of river flow becomes stronger as steeper and longer its track, the stronger surface flow than infiltrate flow, and damaged plants near the bank because of the making of new farming fields that is not in concern with water and land conservation [4].

Soil erosion can affect soil quality. Soil quality is the ability of a soil to function in a variety of ecosystem boundaries to support plant productivity. The disruption of soil function will affect the quality of the soil causing the increase of critical land area, the decrease of soil productivity and environmental pollution. The effect of erosion in reducing soil quality by removing soil surface rich in organic carbon, so that soil fertility decreases. Soil organic carbon is drastically affected by erosion processes
[5]. Soil organic carbon is one of the essential nutrients for plant growth, can be transported along with the runoff. Overland flow transport and move to soil organic carbon together with suspended sediments from agricultural cultivation areas to where the surface water flows halt, into the bodies of river waters.

Overland flow is affected by the global climate condition [6]. In average, radiation received by the earth is in equal to those that are emitted back to the atmosphere after used for evaporation, warming the air and soil surface. This condition is affected by the existence of greenhouse gases (e.g., carbon dioxide, methane, nitrous oxide, ozone and chlorofluorocarbons) which are able to absorb longwave radiation from the earth's surface, so the temperature of earth atmosphere increases [7]. Carbon dioxide $\left(\mathrm{CO}_{2}\right)$ is one of the greenhouse gases that lasts most in the atmosphere [8] and has influence in increasing the atmosphere temperature [9]. The increasing of $\mathrm{CO}_{2}$ emission has reached a dangerous level for earth climate and ecosystem balance now. The tendency is that dry areas will be drier and the other way around with wet areas that become wetter than before. As a result, preservation of water resources is disrupted. If the plants cover area management and soil conservation effort don't take place, it will lead to increase runoff velocity, erosion, loss of soil and soil organic carbon (SOC) in the watershed area. 
Finally, there will be potential for the existence of critical land in that area.

Soil Organic Carbon (SOC) is the carbon associated with organic matter in soils [10], and as the main source of energy for soil microorganisms. Therefore, the ease and speed of SOC availability in the soil are tightly bound with soil organic material (SOM) where it exists. Organic carbon comes in to soil through residues decomposition of plants and animals, root exudates, live and dead microorganisms, and other soil organisms. Organic carbon that comes in to soil will create organic acid complex. Soil Organic Carbon (SOC) is affected by erosion process. Soil carbon can flow along with sediments that come into river flow in form of Particle Organic Carbon (POC), Dissolved Organic Carbon (DOC), and Dissolved Inorganic Carbon (DIC) [5].
Watershed area of Girindulu is dominated by hills and mountains with fault block which is susceptible to erosion. The process of erosion causes the destruction, release, transport of soil material from the upper slopes and the deposition of soil material on the lower slopes. When the transport process of material from the upper slope to the lower slope, there is also a closure of the pores so that the runoff is greater than infiltration. Movement of material from larger upper slopes, potentially landslide, and more intensive sedimentation on the lower slopes. This condition is shown by the existence of cliffs eroded, reveal of plants' root, and rocks on land surface, as well as sedimentation in the river body [4]. It will lead to the potential of creating or causing critical land. Therefore, this research is aimed to analyze critical land based on the erosion and soil organic carbon in the watershed of Girindulu, East Java Province, Indonesia.

Table 1. Landform Unit of Girindulu Watershed [4]

\begin{tabular}{|c|c|c|c|c|c|}
\hline \multirow{2}{*}{$\begin{array}{l}\text { Landforms } \\
\text { Unit }\end{array}$} & \multirow{2}{*}{$\begin{array}{c}\text { Landforms } \\
\text { Genetics }\end{array}$} & \multirow{2}{*}{$\begin{array}{c}\text { Geology } \\
\text { Formation }\end{array}$} & \multirow{2}{*}{$\begin{array}{l}\text { Erosion } \\
\text { Process }\end{array}$} & \multicolumn{2}{|c|}{ Board } \\
\hline & & & & (ha) & $(\%)$ \\
\hline F1 & Fluvial Plains & Aluvium & - & $5,080.74$ & 6.89 \\
\hline D1a & Denudasional Hills & Arjosari Formation & mild eroded & $4,463.41$ & 6.06 \\
\hline D1s & Denudasional Hills & Semilir Formation & mild eroded & $1,401.38$ & 1.90 \\
\hline D1t & Denudasional Hills & Andecite, Dacite Intrusif rock & mild eroded & $1,135.08$ & 1.54 \\
\hline D1w & Denudasional Hills & Watupatok Formation & mild eroded & $7,469.19$ & 10.13 \\
\hline D1wu & Denudasional Hills & Wuni Formation & mild eroded & 74.31 & 0.10 \\
\hline D2a & Denudasional Hills & Arjosari Formation & Moderate eroded & $5,687.96$ & 7.72 \\
\hline $\mathrm{D} 2 \mathrm{t}$ & Denudasional Hills & Andecite, Dacite Intrusif rock & Moderate eroded & $1,079.51$ & 1.46 \\
\hline $\mathrm{D} 2 \mathrm{w}$ & Denudasional Hills & Watupatok Formation & Moderate eroded & $4,483.60$ & 6.08 \\
\hline D2wu & Denudasional Hills & Wuni Formation & Moderate eroded & 799.84 & 1.09 \\
\hline D3a & Denudasional Hills & Arjosari Formation & strong eroded & $10,472.32$ & 14.21 \\
\hline D3t & Denudasional Hills & Andecite, Dacite Intrusif rock & strong eroded & 412.27 & 0.56 \\
\hline $\mathrm{D} 3 \mathrm{w}$ & Denudasional Hills & Watupatok Formation & strong eroded & $3,900.00$ & 5.29 \\
\hline $\mathrm{D} 4 \mathrm{j}$ & Peneplain & Jaten Formatian & - & 381.15 & 0.52 \\
\hline K1wo & Karst Hills & Wonosari Formation & mild eroded & 52.18 & 0.07 \\
\hline K2wo & Karst Hills & Wonosari Formation & Moderate eroded & 692.03 & 0.94 \\
\hline K3wo & Karst Hills & Wonosari Formation & strong eroded & 295.39 & 0.40 \\
\hline $\mathrm{S} 1 \mathrm{j}$ & Structural Hills & Jaten Formatian & mild eroded & $1,057.34$ & 1.43 \\
\hline $\mathrm{S} 2 \mathrm{j}$ & Structural Hills & Jaten Formatian & Moderate eroded & $1,248.30$ & 1.69 \\
\hline S2n & Structural Hills & Nampol Formation & Moderate eroded & 124.16 & 0.17 \\
\hline $\mathrm{S} 3 \mathrm{j}$ & Structural Hills & Jaten Formatian & strong eroded & 512.44 & 0.70 \\
\hline S7.1d & Block Fault Hills & Dayakan Formation & mild eroded & $1,260.00$ & 1.71 \\
\hline S7.1n & Block Fault Hills & Nampol Formation & mild eroded & 389.07 & 0.53 \\
\hline S7.2n & Block Fault Hills & Nampol Formation & Moderate eroded & 272.63 & 0.37 \\
\hline $\mathrm{S} 7.3 \mathrm{j}$ & Block Fault Hills & Jaten Formatian & strong eroded & 362.33 & 0.49 \\
\hline SD1m & Structural Denudasional Hills & Mandalika Formation & mild eroded & $6,197.04$ & 8.41 \\
\hline SD2m & Structural Denudasional Hills & Mandalika Formation & Moderate eroded & $6,460.08$ & 8.76 \\
\hline SD3m & Structural Denudasional Hills & Mandalika Formation & strong eroded & $7,940.00$ & 10.77 \\
\hline Total & & & & $73,703.75$ & $\mathbf{1 0 0 . 0 0}$ \\
\hline
\end{tabular}

\section{MATERIALS AND METHODS}

This research uses a geomorphology approach with a landform unit of analysis. The research population is all forms of land in Girindulu watershed. The research sample is of landform unit that represents the condition of the population. Landform units were made by interpreting SRTM image in 1999 and Landsat-7 ETM image in 2006 for the extraction information of landform, process and level of geomorphic processes. Geological Map scale 1:100,000 sheet:1507-4 Pacitan in 1992, and sheet 1508-1 Ponorogo in 1997 for extraction of geological formation 
and geomorphological information. Map of Rupa Bumi Indonesia scale 1:25.000 sheets: 1507-431 Pacitan, 1508112 Nawangan, 1508-121 Kismantoro, 1507-432 Kebonagung, 1507-433 Bungur, 1507-434 Arjosari, 1507443 Tegalombo from Bakosurtanal for zoning boundary of Girindulu watershed and administrative boundary. Landform map scale 1:100.000, made by overlay thematic maps (landform, geological formation and geomorphic process level). Overlay results obtained 28 samples of landform units are presented in Table 1, and the distribution in Girindulu Watershed is presented in Figure 1 .

Data collection through soil survey, with sampling technique, is purposive sampling. The data collected are Land data; Slope length and slope of the slope, land use, soil conservation, and composite soil sampling. Climatic data include Rainfall (11 years), for analysis of climatic conditions (Theisen polygons) recorded in Arjosari, Pacitan, Tegalombo, Nawangan, Tahunan, Kebonagung stations and date of atmospheric temperature recorded at the Pacitan climatology station.

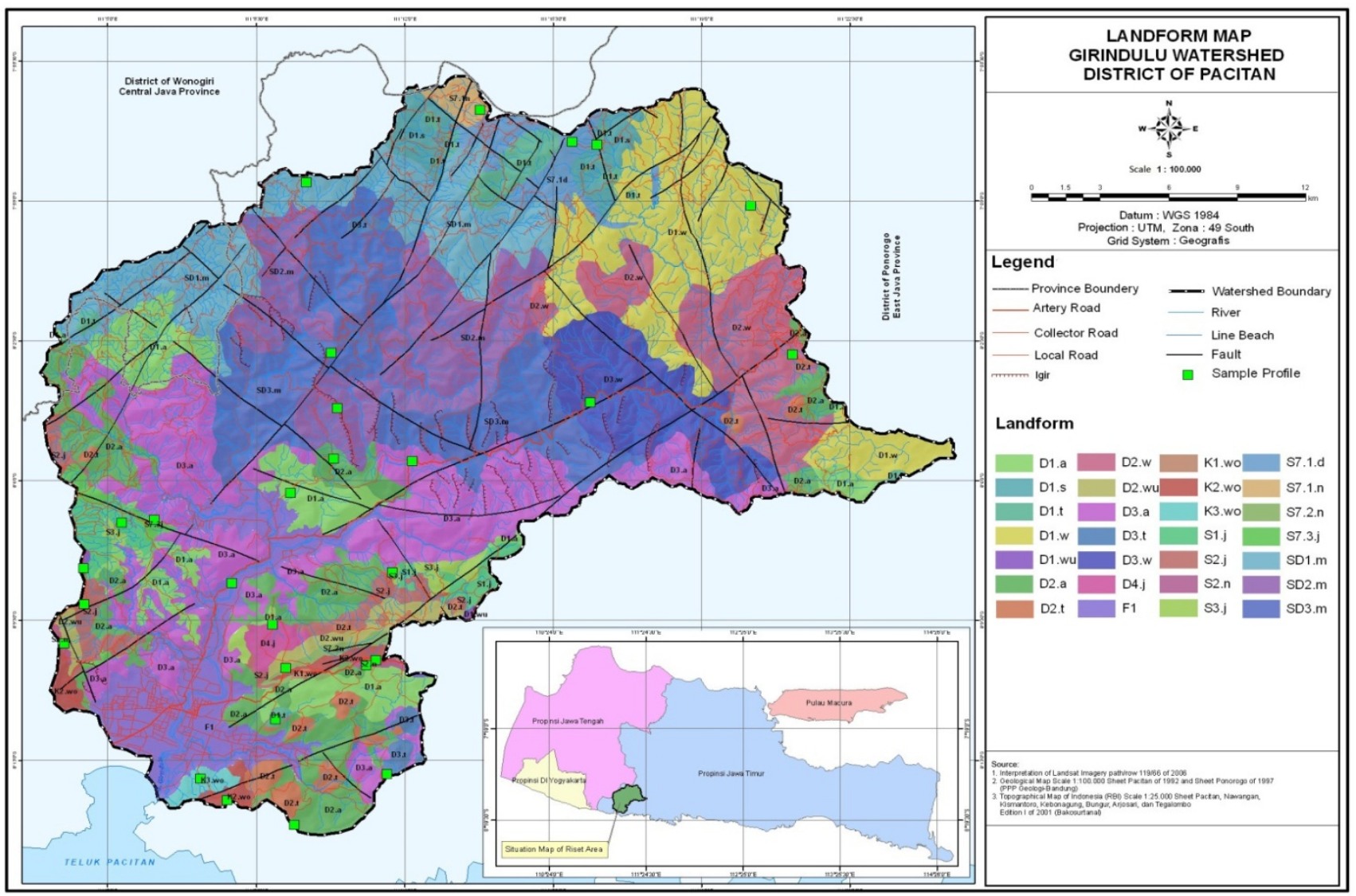

Figure 1. Landform Map of Girindulu Watershed [4]

Data Characteristics of soil through laboratory tests, including: soil texture with hydrometer method, and organic carbon with Walkley black method. Total sediment transported by erosion is predicted using the equation proposed by Mey et. al. [4]:

$$
\begin{aligned}
\text { totSed }=0.6808 & +0.854 C h+0.435 B O-2.125 p L \\
& +1.980 m L
\end{aligned}
$$

where: totSed is total transported sediment (ton/ha), $\mathrm{Ch}$ is the total average rainfall $(\mathrm{cm}), \mathrm{BO}$ is organic material $(\%)$, $\mathrm{pL}$ is the slope length $(\mathrm{m}), \mathrm{mL}$ is slope of the slope (\%), $0.6808 ; 0.854 ; 0.435 ; 2.125$ and 1.980 are statistical constants. The level of erosion hazard is determined by using the existing soil depth approach and the erosion level as its base. The criteria for erosion hazard levels are presented in Table 2 .
Table 2. Erosion hazard levels based on soil solum thickness and the amount of erosion hazard (amount maximum erosion) [11]

\begin{tabular}{|c|c|c|c|c|c|}
\hline $\begin{array}{c}\text { Solum } \\
\text { Thickness }\end{array}$ & \multicolumn{5}{|c|}{$\begin{array}{c}\text { Erosion Maximum (totsed) } \\
\text { (ton/ha/years) }\end{array}$} \\
\hline$(\mathrm{cm})$ & $<15$ & $\begin{array}{c}15- \\
60\end{array}$ & $\begin{array}{c}60- \\
180\end{array}$ & $\begin{array}{c}180- \\
480\end{array}$ & $>480$ \\
\hline$>90$ & SR & S & S & B & SB \\
\hline $60-90$ & R & B & B & SB & SB \\
\hline $30-60$ & S & SB & SB & SB & SB \\
\hline$<30$ & B & SB & SB & SB & SB \\
\hline
\end{tabular}

Note: $\mathrm{SR}=$ Very Low, $\mathrm{R}=$ Low, $\mathrm{S}=$ Medium, $\mathrm{B}=$ Hard, $\mathrm{SB}=$ Very Hard. 
The critically of the land in this research is determined by the class of erosion hazard level and soil organic carbon content, taking into account the value of the soil fraction of silt and clay, with the following assumptions:

1. Uncritical, is landform unit with a very low level of erosion hazard, has soil organic carbon content is very low-very high, with the assumption that the existing soil organic carbon and nutrients are not easily washed due to erosion.

2. Somewhat critical, is landform unit with low to medium level of erosion hazard, has soil organic carbon content is medium-very high, with the assumption that the existing soil organic carbon and nutrients are potentially low for washing due to erosion.

3. Medium critical, is a landform unit with a medium level of erosion hazard, has soil organic carbon content is medium-very high, with the assumption that the existing soil organic carbon and nutrients are potentially medium for washing due to erosion, but soil fertility can still be maintained through fertilizing organically.

4. Critical, is landform unit with medium to a very high level of erosion hazard, has soil organic carbon content is very low-high, with the assumption that the existing soil organic carbon and nutrients are potentially high for washing due to erosion.

5. Very critical, is landform unit with high to very high level of erosion hazard, has soil organic carbon content is very low-low, with the assumption that the existing soil organic carbon and nutrients are potentially very high for washing due to erosion.

\section{RESULTS AND DISCUSSION}

\section{A. Results}

Based on the basic assumptions in land critical assessment, obtained the critical land condition of Girindulu watershed as presented in Table 3, and map of distribution in the research area as shown in Figure 2. Table 3 shows that in landform units of F1 and D4j area of 5.461,89 ha (7.41\%), included in uncritical land category. This is evidenced by the results of research showing that in landform units F1 and D4 occur sedimentation and addition of soil organic carbon [4]. This condition causes the soil to become fertile. The F1 landform unit is not only used for settlement, but also as agricultural cultivation area, even in river body (point bar) during dry season is also used as agricultural cultivation area with planted corn, bean, kale, peanut, and mustard greens. In the landform unit of SD1m area of $6,197.04$ ha $(8.41 \%)$ included in a somewhat critical land category, because it has a class of medium erosion hazard, and high soil organic carbon content $(4.83 \%)$, medium comparative index of soil texture (the content of silt and clay is $79.85 \%$ ). In the landform units of $\mathrm{S} 2 \mathrm{j}, \mathrm{S} 7.1 \mathrm{~d}, \mathrm{~S} 7.1 \mathrm{n}$, and SD3m area of $10,837.37$ ha $(14.70 \%)$ included in medium critical land category, because have medium erosion hazard class, medium soil organic carbon content $(>2 \%)$, heavy-very heavy comparative index of soil texture (content of silt and clay is around 72.40-93.64\%).

Table 3. Critical Condition of Unit Land Shape in Girindulu Watershed

\begin{tabular}{|c|c|c|c|c|c|c|c|c|c|}
\hline \multirow{2}{*}{$\begin{array}{l}\text { Landform } \\
\text { Units }\end{array}$} & \multirow{2}{*}{$\begin{array}{c}\text { Soil Loss } \\
\text { (tons/ha/year) }\end{array}$} & \multirow{2}{*}{$\begin{array}{l}\text { Soil } \\
\text { Deep } \\
(\mathrm{cm})\end{array}$} & \multirow{2}{*}{$\begin{array}{c}\text { Erosion } \\
\text { Hazard } \\
\text { Level }\end{array}$} & \multicolumn{2}{|c|}{$\begin{array}{c}\text { Carbon } \\
\text { Content (C) }\end{array}$} & \multirow{2}{*}{$\begin{array}{c}\begin{array}{c}\text { Silt \& } \\
\text { Clay Content }\end{array} \\
(\%) \\
\end{array}$} & \multirow{2}{*}{$\begin{array}{l}\text { Critical } \\
\text { Land }\end{array}$} & \multicolumn{2}{|c|}{ Large } \\
\hline & & & & $(\%)$ & Class & & & (ha) & $(\%)$ \\
\hline F1 & -37.0 & 86.0 & SR & 0.99 & SR & 40.96 & Uncritically & $5,080.74$ & 6.89 \\
\hline D1a & 211.7 & 76.0 & SB & 1.36 & $\mathbf{R}$ & 61.44 & Very Critical & $4,463.41$ & 6.06 \\
\hline D1s & 120.6 & 100.0 & $\mathbf{S}$ & 1.27 & $\mathbf{R}$ & 79.50 & Critical & $1,401.38$ & 1.90 \\
\hline D1t & 207.4 & 44.0 & SB & 1.22 & $\mathbf{R}$ & 49.77 & Very Critical & $1,135.08$ & 1.54 \\
\hline D1w & 155.5 & 153.0 & $\mathbf{S}$ & 1.42 & $\mathbf{R}$ & 95.49 & Critical & $7,469.19$ & 10.13 \\
\hline D1wu & 179.3 & 60.0 & B & 1.03 & $\mathbf{R}$ & 78.51 & Critical & 74.31 & 0.10 \\
\hline D2a & 152.7 & 102.0 & $\mathbf{S}$ & 1.27 & $\mathbf{R}$ & 57.27 & Critical & $5,687.96$ & 7.72 \\
\hline D2t & 259.0 & 47.0 & SB & 1.76 & $\mathbf{R}$ & 87.71 & Very Critical & $1,079.51$ & 1.46 \\
\hline $\mathrm{D} 2 \mathrm{w}$ & 162.0 & 98.0 & $\mathbf{S}$ & 1.59 & $\mathbf{R}$ & 43.81 & Critical & $4,483.60$ & 6.08 \\
\hline D2wu & 129.4 & 57.0 & SB & 1.96 & $\mathbf{R}$ & 87.54 & Very Critical & 799.84 & 1.09 \\
\hline D3a & 111.1 & 85.0 & B & 1.51 & $\mathbf{R}$ & 7.96 & Very Critical & $10,472.32$ & 14.21 \\
\hline D3t & 171.3 & 55.0 & SB & 3.22 & $\mathbf{T}$ & 80.77 & Critical & 412.27 & 0.56 \\
\hline D3w & 170.9 & 95.0 & $\mathbf{S}$ & 1.21 & $\mathbf{R}$ & 56.40 & Critical & $3,900.00$ & 5.29 \\
\hline $\mathrm{D} 4 \mathrm{j}$ & -133.8 & 70.0 & SR & 2.07 & $\mathbf{S}$ & 86.71 & Uncritically & 381.15 & 0.52 \\
\hline K1wo & 202.8 & 105.0 & B & 1.75 & $\mathbf{R}$ & 85.70 & Critical & 52.18 & 0.07 \\
\hline K2wo & 206.6 & 39.0 & SB & 1.40 & $\mathbf{R}$ & 87.96 & Very Critical & 692.03 & 0.94 \\
\hline K3wo & 229.5 & 100.0 & B & 1.99 & $\mathbf{R}$ & 53.05 & Critical & 295.39 & 0.40 \\
\hline $\mathrm{S} 1 \mathrm{j}$ & 181.6 & 97.0 & B & 2.24 & $\mathbf{S}$ & 79.66 & Critical & $1,057.34$ & 1.43 \\
\hline $\mathrm{S} 2 \mathrm{j}$ & 167.8 & 110.0 & $\mathbf{S}$ & 2.19 & $\mathbf{S}$ & 93.64 & Medium & $1,248.30$ & 1.69 \\
\hline $\mathrm{S} 2 \mathrm{n}$ & 245.3 & 122.0 & B & 2.92 & $\mathbf{S}$ & 95.27 & Critical & 124.16 & 0.17 \\
\hline $\mathrm{S} 3 \mathrm{j}$ & 206.8 & 30.0 & SB & 1.96 & $\mathbf{R}$ & 48.85 & Very Critical & 512.44 & 0.70 \\
\hline S7.1d & 154.1 & 132.0 & $\mathbf{S}$ & 2.49 & $\mathbf{S}$ & 76.45 & Medium & $1,260.00$ & 1.71 \\
\hline S7.1n & 119.9 & 117.0 & $\mathbf{S}$ & 2.30 & $\mathbf{S}$ & 72.40 & Medium & 389.07 & 0.53 \\
\hline S7.2n & 196.6 & 66.0 & SB & 2.01 & $\mathbf{S}$ & 82.61 & Critical & 272.63 & 0.37 \\
\hline $\mathrm{S} 7.3 \mathrm{j}$ & 172.7 & 60.0 & B & 1.32 & $\mathbf{R}$ & 53.90 & Critical & 362.33 & 0.49 \\
\hline SD1m & 133.8 & 150.0 & $\mathbf{S}$ & 4.83 & $\mathbf{T}$ & 79.85 & Rather Critical & $6,197.04$ & 8.41 \\
\hline SD2m & 77.8 & 108.0 & $\mathbf{S}$ & 1.51 & $\mathbf{R}$ & 80.53 & Critical & $6,460.08$ & 8.76 \\
\hline SD3m & 160.0 & 105.0 & $\mathbf{S}$ & 2.17 & $\mathbf{S}$ & 82.30 & Medium & $7,940.00$ & 10.77 \\
\hline Total & 134.1 & & & & & & & 73,703.75 & 100.00 \\
\hline
\end{tabular}


In the landform units of D1s, D1w, D1w, D2a, D2w, D3t, D3w, K1wo, K3wo, S1j, S2n, S7.2n, S7.3j and SD2m area of $32,052.82$ ha $(43.49 \%)$ are included in critical land category, because they have medium-very heavy erosion hazard class, low soil organic carbon content $(<2 \%)$, Medium-very heavy comparative index of soil texture (content of silt and clay is around 53-95\%). In the landform units of D1a, D1t, D2t, D2wu, D3a, K2wo and $\mathrm{S} 3 \mathrm{j}$, area of $19,154.63$ ha $(25.99 \%)$ are included in very critical land category, because they have heavy and very heavy erosion hazards class, low soil organic carbon content $(<2 \%)$, very low-very heavy comparative index of soil texture (content of silt and clay is around 7.96$87.96 \%)$.

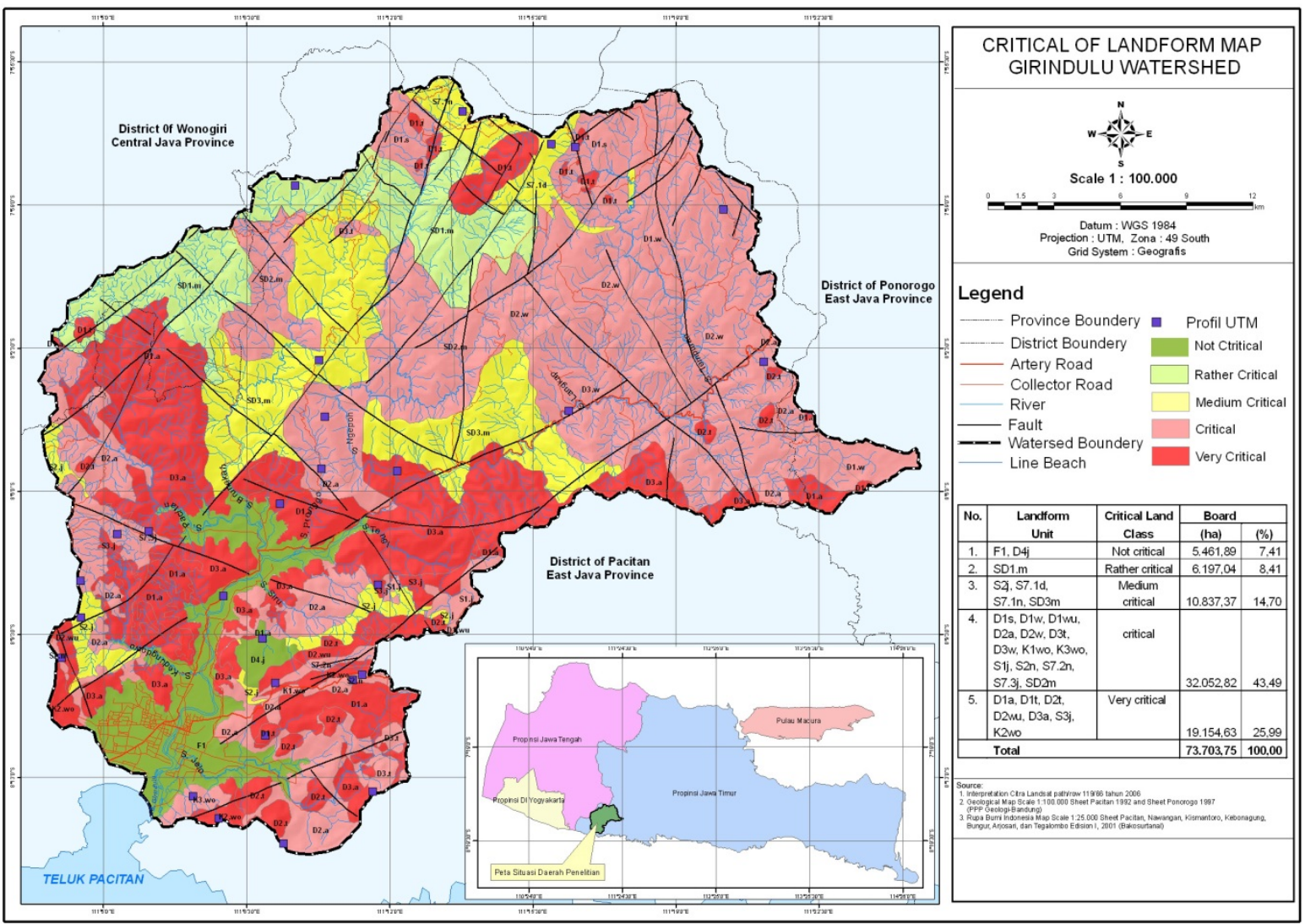

Figure 2. Critical of landform map Girindulu watershed

\section{B. Discussion}

Erosion affecting critical land due to erosion can lead to soil loss exceeding the speed of the soil formation process, resulting in degraded land and reduced functionality. Conditions of erosion hazard level (EHL) will affect the sustainability of land functions. The land conditions with low erosion hazard level (EHL) will provide sustainable land use, whereas if land conditions with high-very high erosion hazard level, will threaten the sustainability of land functions.

In landform units of belonging to the rather land critical category and medium, have a medium level of erosion hazard. This condition can still be utilized for the development of agricultural cultivation work, by applying good soil conservation techniques and organic fertilizing. In the landform units this have medium to high organic matter content. Soils with high organic matter content have the ability to reduce erosion so that the soil remains fertile. The higher the content of organic matter in the soil, the higher the ability of water absorption by the soil and causes the longer of saturation process in the soil to absorbing water. Conversely, reduced soil organic matter will reduce aggregate stability, weakening the structure of the soil, and negative impact on soil water availability to plants [12].

In addition, the medium-high of soil organic matter content, causing soil aggregate becomes more stable, soil structure becomes better, soil ability to store water better also, thus reducing the occurrence of soil erosion [4]. This is identical with Kay (1998) and Yoder (1936) statements in Starr et al. [13] that soil organic carbon plays a role to stabilize aggregates, and thereby reducing susceptibility to erosion. In the landform units this, have a fine soil texture. This condition can reduce the erosion process, and able to maintain the condition of soil organic matter. Starr et al., [13] stated that soil organic carbon flows simultaneously with the flow of sediments carried by runoff, influenced by the stable aggregate size of soil eroded. The role of soil organic carbon to critical land is by improving soil fertility status. The higher the organic carbon content in the soil, soil fertility status also increases so that soil productivity tends to increase.

In the landform units of belonging to the critical and very critical land category, it is more dominated by mediumvery high erosion hazard levels, with low organic matter conditions $(<2 \%)$. Soil conditions containing low organic matter will be very easily eroded, so it has the potential to become critical. If used for agricultural cultivation work, 
land conditions with high-very high erosion hazard levels need to apply proper soil conservation techniques. The results of previous erosion studies indicated that land use without regard to soil conservation techniques resulted in a soil erosion of $35-86 \mathrm{Mg} / \mathrm{ha} /$ year [14]; 225.3 tons [15]; 28.3-56.9 tons/ha in 1994 and 29.7-55.5 tons/ha in 1995 [16]; 6.7-9.7 $\mathrm{km}^{-2} \mathrm{yr}^{-1}$ [17]. The results of this research provide an illustration that the land with high-very high erosion hazard level, if cultivated for agricultural crops without soil conservation, will easily erode, thus threatening the sustainability of land functions.

\section{CONCLUSION}

The critical land extremely depends by the process of erosion, soil texture and soil organic carbon content. Erosion process can cause a land to be critical or not critical. It is shown by research result, that indicates Girindulu Watershed area of 73,703.75 ha, no critical land area of 5.461 .89 ha $(7.41 \%)$, somewhat critical of 6.197 .04 ha $(8.41 \%)$, medium critical of 10.837 .37 ha $(14.70 \%)$, critical land of $32,052.82$ ha $(43.49 \%)$, and very critical land area of $19,154.63$ ha $(25.99 \%)$.

\section{ACKNOWLEDGMENT}

The authors would like to express their gratitude to the Ministry of National Education of Indonesia for funding this research through doctoral grants Number: 097 / PPK / Unhalu / V / 2013. We would like to thank the Faculty of Geography, UGM for supporting the equipment, Pacitan government for providing secondary data for this study, and Bakosurtanal for the Map of Rupa Bumi Indonesia. We also thank the two anonymous reviewers for their constructive comments, which substantially contributed to the improving of the quality of the manuscript.

\section{REFERENCES}

[1] Prasetyo, S.Y.J.; Hasiholan, B.; Hartomo, K.D.; Paseleng, M.; Nuswantoro, B. Geographic Information System of Critical Level of Land Degradation (Critical Land) Based on Agroecological Zone (AEZ) in Agricultural Areas with Recombination. International Journal of Computer Science Issues 2013, 10, 217-221.

[2] Fang, N.F.; Shi, Z.H.; Li, L.; Guo, Z.L.; Liu, Q.J.; $\mathrm{Ai}, \mathrm{L}$. The Effects of Rainfall Regimes and Land Use Changes on Runoff and Soil Loss in a Small Mountainous Watershed. Journal Catena 2012, 99, $1-8$.

[3] Wang, L.; Shi, Z.H.; Wang, J.; Fang, N.F.; Wu, G.L.; Zhang, H.Y. Rainfall Kinetic Energy Controlling Erosion Processes And Sediment Sorting On Steep Hillslopes: A Case Study Of Clay Loam Soil From The Loess Plateau, China. Journal of Hydrology 2014, 512, 168-176.

[4] Mey D.; Sartohadi, J.; Mardiatno, D.; Marfai, M.A. Prediction of Soil Organic Carbon Loss Due to Erosion in the Girindulu Watershed of Central
Java. Journal of Degraded and Mining Lands Management 2015, 2, 327-334.

[5] Lal, R. Soil Erosion and Global Carbon Budget. Journal Environment International 2003, 29, 437 450

[6] Hanson, R.T.; Dettinger, M.D. Ground water/surface water responses to global Climate simulations, santa clara-calleguas Basin, ventura, California. Journal of The American Water Resources Association 2005, 03162, 517-536.

[7] Zein, A.L.; Chehayeb, N.A. The Effect of Greenhouse Gases on Earth's Temperature. International Journal of Environmental Monitoring and Analysis 2015, 3, 74-79.

[8] Wallington, T.J.; Srinivasan, J.; Nielsen, O.J.; Highwood, E.J.' Greenhouse Gases and Global Warming. Environmental and Ecological Chemistry 2004, [Ed. Aleksandar Sabljic], in Encyclopedia of Life Support Systems (EOLSS), Developed under the Auspices of the UNESCO, Eolss Publishers, Oxford ,UK, [http://www.eolss.net].

[9] Hansen, J.; Johnson, D.; Lacis, A.; Lebedeff, S.; Lee, P.; Rind, D.; Russell, G. Climate Impact of Icreasing Atmospheric Carbon Dioxide. Science 1981, 213, 957-966.

[10] Liddicoat, C.; Schapel, A.; Davenport, D.; Dwyer, E. 2010. PIRSA Discussion Paper: Soil Carbon and Climate Change. Rural Solution SA 2010, Government of South Australia.

[11] Hardjowigeno, S.; Widiatmaka. Evaluasi Lahan Dan Perencanaan Tataguna Lahan. Bogor: IPB Press: Bogor, Indonesia, 2001; pp.

[12] Karlen, D.L.; Rice, C.W,. Soil Degradation: Will Humankind Ever Learn?. Sustainability 2015, 7 , 12490-12501.

[13] Starr, G.C.; Lai, R.; Malone, R.; Hothem, D.; Owens, L.; Kimble, J. Modeling Soil Carbon Transported By Water Erosion Processes. Journal Land Degradasion and Development 2000, 11, 8391.

[14] Ranieri, S.B.L.; Lier, Q.D.J.V.; Sparovek, G.; Flanagan, D.C. Erosion Database Interface (EDI) A Computer Program For Georeferenced Application of Erosion Prediction Models. Journal Computers and Geosciences 2002, 28, 661-668.

[15] Takken, I.; Govers, G.; Jetten, V.; Nachtergaele, J.; Steegen, A.; Poesen, J. The Influence of Both Process Descriptions and Runoff Patterns on Predictions From A Spatially Distributed Soil Erosion Model. Journal Earth Surface Processes and Landforms 2005, 30, 213-229.

[16] Veihe, A.; Rey, J.; Quinton, J.N.; Strauss, P.; Sancho, F.M.; Somarriba, M. Modelling of EventBased Soil Erosion in Costa Rica, Nicaragua and Mexico: Evaluation of The EUROSEM Model. Journal Catena 2001, 44, 187-203.

[17] Lobb, D.A.; Kachanoski, R.G. Modelling Tillage Erosion in The Topographically Complex Landscapes of Southwestern Ontario, Journal Soil and Tillage Research 1999, 51, 261-277. 